\title{
Assessing Nighttime Place Identity using Measurable Indicator Scoring Technique
}

\author{
Mohd Riduan Ngesan¹, Syed Sobri Syed Zubir² \\ ${ }^{1}$ Centre for Environment-Behaviour Studies \\ ${ }^{2}$ Centre for Architecture Studies \\ Faculty of Architecture, Planning \& Surveying \\ Universiti Teknologi MARA, Shah Alam 40450, Malaysia \\ nightcityconcept@gmail.com
}

\begin{abstract}
This paper is a comparative study of place identity of nighttime urban public parks between Shah Alam that was built in 1957 and Putrajaya in 1999. This study used four research domains that form place identity adapted from Relph, 1976 and Cheshmehzangi, 2012. The method of this study involves the behavior mapping survey and the questionnaire survey. The data were then analysed using Measurable Indicator Scoring Technique (Karim, 2008) to ensure constant comparative process by creating analytic codes. It is hope that the findings from this study would help to improve the place identity and functions of future nighttime urban public parks.
\end{abstract}

Keywords: Nighttime place identity; urban public park; Measurable Indicator Scoring Technique

eISSN 2398-4295 @ 2018. The Authors. Published for AMER ABRA cE-Bs by e-International Publishing House, Ltd., UK. This is an open-access article under the CC BY-NC-ND license (http://creativecommons.org/licenses/bync-nd/4.0). Peer-review under responsibility of AMER (Association of Malaysian Environment-Behaviour Researchers), ABRA (Association of Behavioural Researchers on Asians) and cE-Bs (Centre for EnvironmentBehaviour Studies), Faculty of Architecture, Planning \& Surveying, Universiti Teknologi MARA, Malaysia.

DOI: http://dx.doi.org/10.21834/ajbes.v3i12.119 


\subsection{Introduction}

Place identity could best be understood as that which makes a place unique. Proshansky et al. (1983) define place identity as a potpourri of memories, conceptions, interpretations, ideas, and related feelings about specific physical settings, as well as the types of setting. Although the time factor has been mentioned by many researchers as part of essential elements for space analysis (Proshansky and Fabian, 1987; Hague and Jenkins, 2005); the time used by those researchers refer more on the time decade or climate season rather than daily time. Thus, this research examines the space by considering the nighttime as part of a cycle in the daily time. Moreover, the heat temperature during the day especially for a tropical country or during summer time has reduced urban community leisure activities in outdoor areas (Shaharudin et al., 2010). Furthermore, the busy lifestyle of urban community during the day also affects the lack of time for leisure and recreation activities in public outdoor areas (Oguz and Cakci, 2010). These constraints have changed the behavioural patterns of the urban communities where people prefer to carry out their leisure activities in the public park after the sun has set. Although there are safety issues for urban public parks to be used at night due to the probability of crime activities, it might be reduced if there are proper designs in planning guidelines of open spaces and recreation areas that accommodate for community nighttime leisure activities. Moreover, a good public space must be able to be used by everyone regardless of the time of day (Jacobs, 2002). Nowadays, the community's activities during the night are usually conducted in the place indoors (Erkip, 2003). However, these kinds of leisure activities cannot be afforded by everyone since it requires the cost of money. The practice of indoor rather than open and green outdoor spaces for leisure activities has led to a more passive urbanite lifestyle. People neglect the fact that physically active lifestyle with outdoor green environment are important in terms of physical and mental health (Oguz and Cakci, 2010). Thus, the optimization usage of outdoor green spaces in crucial. It is also critical to examine the place identity of nighttime urban public park because place identity has significantly supports theoretical values of spatial quality and society's well-being (Nasir et al., 2013).

\subsection{Literature Review}

Cheshmehzangi (2012) argues that public sphere could appear in many ways and that by itself, have no definite identity. Therefore, public realm does not have a certain identity but rather is fulfilled with several changing identities influenced by content (person or object) and context (culture or environment) where content is the inherent value (Relph, 1976). Thus, the urban public parks which are used during the night by the urban community especially in the tropical or hot humid country such as Malaysia, will have its own place identity. There are four research domains involved for this study adapted from Relph (1976) and Chesmehzangi (2012). According to Relph (1976), identity of the place involves three interrelated elements where each of elements is irreducible to the other, namely physical features or appearance, observable activities and function, and meaning or symbol. However, Chesmehzangi (2012) argues that place identity can also be comprised into three generalised forms based on earlier elements that mention by Relph (1976). Similar to this, the physical elements and 
features can be considered as a navigation mechanism that can also be as a visual tool by acknowledging the image element. The structure of interrelations can be regarded as the perceptual form of place identity and the actions and the spatial interrelation can be recognised as a behavioural tool. This study adapts the elements that form place identity proposes by Relph (1976) and then later generalises as tools by Cheshmehzangi (2012); into research domains comprising the research topic which is the implication of nighttime leisure activities towards place identity of urban public park. Therefore, the behavioural tool can be considered as the nighttime leisure behaviour in urban public park domain, the perceptual form can be considered as the perception on nighttime leisure domain, and the visual tool can be considered as the image of nighttime urban public park domain. This study also is therefore believed to add to another research domain which is the socio-demographic and leisure profile domain because identity of the place is a spatial inter-relations. Additionally, it is not only the place that needs to be studied but also the humans themselves as users of the place (Cheshmehzangi, 2012).

\subsection{Methodology}

This research is conducted in urban public parks situated in the respective city centre of Shah Alam and Putrajaya that adapt the garden city concept. However, Shah Alam was built earlier in 1957 as the state capital of Selangor while Putrajaya later in 1999 as a federal administrative centre of Malaysia. Through the evolution of time, the of process urbanisation, the influence of neighbouring city areas, the methods of interpretation of garden city concepts, and the different scale and function of urban development; are anticipated to produce an interesting results. However, the comparison between place identity of urban public park during the day is also not be included. There are four the research domains involved for this study namely: (D1) Nighttime leisure behaviour in urban public park domain; (D2) Socio-demographic and leisure profile of respondents domain; (D3) Perception on nighttime leisure domain; and (D4) Image of nighttime urban public park domain. Each of research domains consists the variables gathers from the literature reviews, exploratory study (expert interview survey) and earlier observation survey conducted in study areas at night. This study used two types of survey to collected the data of research domains namely (1) behaviour mapping survey for D1, and (2) questionnaire survey for D2, D3, and D4.

The results from both surveys were then combined using Measurable Indicator Soring Technique (MIST) adapted by Karim (2008). MIST was developed based an idea adapted from grounded theory to overcome the contradictions between qualitative and quantitative research. MIST also used to integrate and formalising relationship of research domains by producing a conceptual framework at the final stages. According to Dey (1999), the steps of grounded theory research occur simultaneously that meant the researcher will be observing, collecting data, organising data and forming theory from the data at the same time. One important methodological technique in grounded theory that applied in MIST is the constant comparative process in which every piece of data is compared with every other piece. Data collection and analysis are consciously combined, and initial data analysis is used to shape continuing data collection. This is processed provide the researcher with opportunities to 
increase the density and saturation of recurring categories (Strauss and Corbin, 1998). This study has used several surveys which are used to continuing data collection from expert interview survey, pilot surveys, behaviour mapping survey and questionnaire survey. Charmaz (2006) indicates that, grounded theories included a creation of analytic codes developed from primary data and not by pre-existing conceptualisations of theoretical sensitivity. Since there were many types of data collected from different survey, this study had therefore adopted the analytical codes known as grading technique to measure data for constant comparative process. This technique will be used to summarize the findings of all research domains by giving a score to the items studies based on the results from descriptive statistical analysis in behaviour mapping survey and questionnaire survey. The scores were distributed based on various types of grading technique founded from value of frequency, percentage, and the Mean value of Likert scale. There were three ranking level in the scoring formulates in this technique namely: (1) Weak, (2) Satisfactory or (3) Strong. The total of Strong score determines which study area received a higher relation to place identity of nighttime urban public park. The results were also used to develop a conceptual framework of place identity of nighttime urban public park based on the ranking of Strong score for each research domains.

\subsection{Results and Discussions}

Table 1. The comparing results of MIST by research domains

\begin{tabular}{|c|c|c|c|c|c|c|c|c|c|c|}
\hline \multirow{2}{*}{$\begin{array}{l}\text { Research } \\
\text { Domain }\end{array}$} & \multirow[t]{2}{*}{ MIST } & \multicolumn{3}{|c|}{ Shah Alam } & \multicolumn{3}{|c|}{ Putrajaya } & \multicolumn{3}{|c|}{ Average Study Area } \\
\hline & & 1 & 2 & 3 & 1 & 2 & 3 & 1 & 2 & 3 \\
\hline \multirow[t]{2}{*}{$\mathrm{D} 1$} & Score & 17 & 4.5 & 6.5 & 28 & 0 & 0 & 22.5 & 2.25 & 3.25 \\
\hline & & 60.7 & 16.1 & 23.2 & $\sqrt{100.0}$ & 0.0 & 0.0 & 80.4 & 8.0 & 11.6 \\
\hline \multirow[t]{2}{*}{$\mathrm{D} 2$} & Score & 3 & 6 & 1 & 2 & 5 & 3 & 2.5 & 5.5 & 2 \\
\hline & & 30.0 & 60.0 & 10.0 & 50.0 & 50.0 & 30.0 & 25.0 & 55.0 & 20.0 \\
\hline \multirow[t]{2}{*}{ D3 } & Score & 0 & 12 & 41 & 0 & 3 & 50 & 0 & 7.5 & 45.5 \\
\hline & $\%$ & 0.0 & 22.6 & 77.4 & 5.0 & 5.7 & 94.3 & 0.0 & 14.2 & 85.8 \\
\hline \multirow[t]{2}{*}{ D4 } & Score & 0 & 5 & 12 & 0 & 0 & 17 & 0 & 2.5 & 14.5 \\
\hline & $\%$ & 0.0 & 29.4 & 70.6 & 0.0 & 0.0 & 100.0 & 0.0 & 14.7 & 85.3 \\
\hline \multirow[t]{2}{*}{ Total } & Score & 20 & 27.5 & 60.5 & 30 & 8 & 70 & 25 & 17.75 & 65.25 \\
\hline & & 18.5 & 25.4 & 56.1 & 27.8 & 7.4 & 64.8 & 23.1 & 16.4 & 60.5 \\
\hline
\end{tabular}

Note: Likert scale MIST: 1=Weak, 2=Satisfactory, 3=Strong.

Referring to Table 1. the results of the MIST showed Putrajaya received the higher Strong score for Socio demographic and leisure profile of the respondent domain, Perception on nighttime leisure in urban public park domain, and Image of nighttime urban public park domain compare to Shah Alam. However, Shah Alam only received higher Strong score for the Nighttime leisure behaviour in urban public park domain compare to Putrajaya. Overall, Putrajaya received higher Strong score with 64.8 per cent compared to Shah Alam whose 56.1 per cent. Thus, the designed places of urban public parks in both areas are able to capture and support the nighttime leisure activities of urban community. The final results of MIST were combined to produce a conceptual framework based on the ranking order of 
Strong score of research domains in each case study areas (Table 2.). This ranking showed the priority while designing and determining the place identity of urban public park during nighttime.

Table 2. The conceptual framework of place identity of nighttime urban public park based on ranking order of research domains

\begin{tabular}{|c|c|c|c|c|c|c|}
\hline $\begin{array}{l}\text { Ranking } \\
\text { Order }\end{array}$ & Shah Alam & $\begin{array}{l}\text { Strong } \\
\text { Score (\%) }\end{array}$ & Putrajaya & $\begin{array}{l}\text { Strong } \\
\text { Score (\%) }\end{array}$ & $\begin{array}{c}\text { Average Study } \\
\text { Area }\end{array}$ & $\begin{array}{l}\text { Strong } \\
\text { Score }(\%)\end{array}$ \\
\hline 1 & $\begin{array}{c}\text { Perception on } \\
\text { nighttime leisure }\end{array}$ & 77.4 & $\begin{array}{l}\text { Nighttime image of } \\
\text { urban public park }\end{array}$ & 100.0 & $\begin{array}{c}\text { Perception on } \\
\text { nighttime leisure }\end{array}$ & 85.8 \\
\hline 2 & $\begin{array}{l}\text { Nighttime image of } \\
\text { urban public park }\end{array}$ & 70.6 & $\begin{array}{c}\text { Perception on } \\
\text { nighttime leisure }\end{array}$ & 94.3 & $\begin{array}{l}\text { Nighttime image of } \\
\text { urban public park }\end{array}$ & 85.3 \\
\hline 3 & $\begin{array}{l}\text { Nighttime leisure } \\
\text { behaviour in } \\
\text { urban public park }\end{array}$ & 23.2 & $\begin{array}{c}\text { Socio } \\
\text { demography and } \\
\text { leisure profile of } \\
\text { respondent }\end{array}$ & 30.0 & $\begin{array}{l}\text { Socio demography } \\
\text { and leisure profile of } \\
\text { respondent }\end{array}$ & 20.0 \\
\hline 4 & $\begin{array}{l}\text { Socio demography } \\
\text { and leisure profile } \\
\text { of respondent }\end{array}$ & 10.0 & $\begin{array}{l}\text { Nighttime leisure } \\
\text { behaviour in } \\
\text { urban public park }\end{array}$ & 0.0 & $\begin{array}{l}\text { Nighttime leisure } \\
\text { behaviour in } \\
\text { urban public park }\end{array}$ & 11.6 \\
\hline
\end{tabular}

The results from the conceptual framework indicated that, the research domains are placing in a different rank in both of study areas. This shows that each of study areas perceived place identity in a distinct way. Thus, this study demonstrates that the evolution of time, the of process urbanisation, the influence of neighbouring city areas, the methods of interpretation of garden city concepts, and the different scale and function of urban development; are able to affect the priority while determining the ranking of place identity domains. This evidence supports the argument by Cheshmehzangi (2012) that, public realm could appear in many ways. The findings also support the argument by Relph (1976) that, public realm does not have a certain identity and experiencing changing identities influenced by content (person or object) and context (culture or environment) where content is the inherent value. The results of MIST in both of study areas were then combined to shows the general conceptual framework of place identity for nighttime urban public parks according to the ranking of research domains.

The average results of study areas exhibited that the first rank is the perception of nighttime leisure domain. This result supports the argument by Twigger-Ross et al. (2003) that, place identity theory does not provide much detail regarding the structure but describe as perceptions and ideas that affect the physical environment. This research found that, the majority of respondents were agreed to all of variables studies in this research domain. For this, Harvey (1996) asserts spirituality of a place can only become definable by concentration of meaningful perceptions in place. Moreover, user's perceptions regarding place identity are related with the density and crowd in nighttime urban public parks. According to Montano and Adamopoulos (1984), the effect of crowded in environmental psychology exists creates situational such as feeling constrained or having expectations dashed, emotional that usually negative, but positive emotions can occur, and behavioural such as activity completion or 
assertiveness. Thus, the size of areas for nighttime leisure in urban public park should be enhanced to cater the crowd of nighttime users because competition between spaces and users would affect the users perception on nighttime leisure.

The second rank is the image of nighttime urban public park domain. Cheshmehzangi (2012) argues that, understanding a place comes from visibility and creation of place as an image whether inclusive or collective to emphasise the importance of physicality of the place. This research found that, the majority of respondents were agreed to all variable studies in this research domain. Results from average MIST showed that, there merely slightly different scoring between the first rank (D3) and the second rank (D4) of the research domain. However, there are clear different results of D3 and D4 while compared the Strong score in Putrajaya and Shah Alam. The scoring of D3 and D4 in Putrajaya is higher compared to Shah Alam. Meanwhile, the scoring of D1 in Putrajaya is lower compared to Shah Alam. This finding also relates to the density and crowd in nighttime urban public parks as mentioned earlier by Montano and Adamopoulos (1984).

The third rank is the socio-demography and leisure profile domain. It is found that the majority of marriage groups are preferred to use the urban public park during nighttime. There are many advantages to being married. Gans (1962) said that married people tend to have a stabilising effect on the community and very concern about the living condition including leisure. Since the majority of the respondents are married, there are also many children in the study area. However, there are also relatively many singles in Shah Alam compared to Putrajaya being young factory worker and university students. From the aspect of house ownership, majority of respondents are rental and have lived less than five years. Parkes et al. (2002) showed that people in residence over five years were less likely to exhibit decreased neighbourhood satisfaction than others, suggesting that neighbourhood attachment increase in the five to ten years residence period including in the urban area. Moreover, Auh and Cook (2009) highlight that, residents who lived more than 5 years in the areas are likely to be emotionally attached to the place and express more community knowledge and pleasure than short-term residents. It is not just the identity of a place that is important, but also the identity that a person or group has with that place in particular whether they are experiencing it as an insider or an outsider (Relph, 1976). This study showed that the majority of users are preferred used the nighttime urban public park during the weekend and related to the satisfaction and frequency of using playground in their housing areas.

The fourth and last rank is the nighttime leisure behaviour in urban public park domain. The study found that the majority of nighttime leisure activities in urban public park are categorised as sedentary level. Thus, the nighttime urban public park should provide appropriate design that can cater for sedentary leisure category according to different age of groups. The majority of users are also among a group of families. Community with children helps to promote a family-friendly environment with good social network for both children and parents, and create a natural constituency for maintaining aspect of the community that are important to families (Schiller and Muller, 2000). The present of families with the children in the urban area signify that the parents have consider the area good place to raise children. It also was found that the majority of users are males. However, there is only slightly different between numbers of user's males and female. The majority of the standing position while 
carried out nighttime leisure shows that the users actively used the space for nighttime leisure activities of sedentary level. The higher users used urban public park is on 10.30 p.m. However, the number of users also is still high even after 12 midnight. These shows that the urban communities are enjoy using urban public parks as outdoor areas for nighttime leisure.

\subsection{Conclusion}

This study had briefly described the findings by producing a conceptual framework of place identity for nighttime urban public park. This conceptual framework can be applied while designing public park for nighttime used from the of place identity perspective. It shows the priority indicators involved to achieving the strong preference of place identity. There are two types of the conceptual framework were derived from the research domains. This study has found that the place identity of urban public parks is affected by the by the research domain in a different way. There are many factors that affect the place identity of urban public parks such as the urbanisation process of city, the size of the population, the influential of neighbouring city areas and many more. Therefore, the influences of each research domain in each of case study areas differ. However, since the scoring of place identity in both of study areas are merely satisfied, the further studies are proposed to be carried out to investigate the appropriate physical design of urban public park that can be used during the day and also able to sustain the users during nighttime. As this study is confined to the urban public parks in Shah Alam and Putrajaya that adopted the concept of garden city, it is suggested that future research should involve more samples of urban parks nationwide with different adoption of city concepts.

\section{Acknowledgement}

The authors would like to acknowledge Universiti Teknologi MARA, Shah Alam City Council and Putrajaya Corporation for their endless assistance given during the course of carrying out the study. This study was funded by Research Intensive Faculty (Grant 600-RMI/DANA 5/3/RIF 264/2012), managed by Research Management Institute, Universiti Teknologi MARA.

\section{References}

Auh, S., \& Cook, C. (2009). Quality of community life among rural residents: An integrated model. Springer Science Business. Media B.V.

Charmaz, K. (2006). Constructing Grounded Theory: A Practical Guide through Qualitative Analysis. London Sage Publications.

Cheshmehzangi, A. (2012). Identity and public realm. Procedia Social and Behavioural Sciences. 50. Pp307-317. 
Ngesan, M.R., \& Syed Zubir, S.S. / Asian Journal of Behavioural Studies (AjBeS), 3(12) Jul / Aug 2018 (p.23-30)

Dey, I. (1999). Grounding Grounded Theory Guidelines for Qualitative Inquiry. San Diego: Academic Press.

Erkip, F. (2003). The shopping mall as an emergent public space in Turkey. Environment and Planning, 35, 10731093.

Gans, H. (1962). The urban villagers. New York: The Free Press.

Hague, C., \& Jenkins, P. (2005). Place identity, planning and participation. London: Routledge.

Harvey, D. (1996). Justice, nature and the geography of difference. Oxford: Blackwell.

Jacobs, J. (2002). The death and life of great American cities. New York: Random House.

Karim, H.A. (2008). The quality of life of residents of urban low cost flats in Klang and Shah Alam. Unpablished PhD. Thesis UKM, Bangi.

Montano, D., \& Adamopoulos, J. (1984). The perception of crowding in interpersonal situations: Affective and behavioral responses. Environment and Behavior, 16, 643-666.

Nasir, R.A., Ahmad, S.S., \& Ahmed, A.Z. (2013). Physical activity and human comfort correlation in an urban park in hot and humid conditions. Procedia - Social and Behavioral Sciences, 105, 598-60.

Oguz, D., \& Cakci, I. (2010). Changes in leisure and recreational prefrences: A case study of ankara. Scientific Research and Esseys, 5(8), 721- 729.

Parkes, A., Kearns, A., \& Atkinson, R. (2002). What makes people dissatisfied with their neighbourhoods? Urban Studies, 39(13) 2413-2438.

Proshansky, H.M., \& Fabian, A.K. (1987). The quality of urban life. Walter de Gruyter \& Co. New York.

Proshansky, H.M., Fabian, A.K., \& Kaminoff, R. (1983). Place-identity: Physical world socialization of the self. Journal of Environmental Psychology, 3, 57-83.

Relph, E. (1976). Place and placelessness, London: Pion Limited.

Schiller, A., \& Muller, C. (2000). Lavelling the playing field. Standart educational attainment and state's performance testing. Sociology of Education. 73. 196-218.

Shaharuddin, A., Noorazuan, M. H, Yaakob, M. J., Kadaruddin, A., \& Mohd Fahmi, M. (2010). The effect of different land uses on the temperature distribution in urban areas. SEAGE 2010, Hanoi 23- 26 Nov 2010. Onlice proceeding.

Strauss, A., \& Corbin, J. (1998). Basics of qualitative research techniques and procedures for developing grounded theory (2nd ed), Thousand Oaks: Sage Publications.

Twigger-Ross, C.L., Bonaiuto, M., \& Breakwell, G. (2003). Identity theories and environmental psychology. Aldershot, England: Ashgate. 